\title{
EMDR : An Alternative Effective Tool for Reduction of Academic Stress?
}

\author{
Frischa Meivilona Yendi ${ }^{1 *}$, R Tririzky ${ }^{2}$, Firman Antoni ${ }^{3}$, Ifdil Ifdil ${ }^{4}$, Indah Sukmawati ${ }^{5}$ \\ ${ }^{1234}$ Guidance and Counseling, Faculty of Education,Universitas Negeri Padang, Indonesia
}

\begin{abstract}
The stress often experienced by students is academic stress. Academic stress is a situation where students cannot face academic demands and the exception of the academic demands received as a disorder. If not handled properly, it will disrupt the effectiveness of learning and absorption of information on students. This study aims to reveal the effect of EMDR (Eye Movement Desensitization and Reprocessing) in reducing student academic stress. The research method is an experimental study conducted with a repeated measure pretest and multiple posttest design. The subjects in this study were 15 students. The instrument used was an adaptation of the Academic Stress Inventory of students at universities and colleges of technology from Lin and Chen. Analyze the data using the one-way ANOVA for repeated measures. The results showed that EMDR is proven to be one of the effective tools to reduce academic stress on students.
\end{abstract}

Keywords

EMDR; Academic stress

Article Received: 20 September 2020, Revised: 30 November 2020, Accepted: 18 December 2020

\section{Introduction}

The student is one college of the colleges. Students are at the transition from late adolescence to early adulthood, demanding some adjustments in various aspects of life. Individuals who are attending college must complete the study load to graduate with at least 144 credits for a bachelor's degree (Nomor, 2015 ). Various tasks and roles and responsibilities that must be undertaken as students need time in adjusting from the habit in the previous education bench. However, many of the students are less understanding of the responsibilities and obligations that have to be holding in carrying out their roles. So many students are experiencing stress.

Stress is a human psychophysical phenomenon in the sense that stress is inherently inherent in every person in living his or her daily life. Stress occurs when there is an imbalance between the demands with the ability, the stress experienced by the student closely related to the source of stress (Lazarus \& Folkman, 1984). The stress often experienced by students is academic stress (Simbolon, 2015). Academic stress is a situation where students cannot face academic demands and the exception of the academic demands received as a disorder (Barseli, Ahmad, \& Ifdil,
2018). Academic stress occurs because of students unable to fulfill demands in carrying out their roles as students.

Based on research that has been conducted Akgun \& Ciarrochi (Akgun \& Ciarrochi, 2003), high academic stress can cause adverse effects on academic ability for low-value students, but has no effect on high-value students. Loads that are too heavy can also trigger memory impairment, impaired concentration, the decrease in the ability to solve problems and academic ability (Rusdi, 2015; Yuliasih \& Akmal, 2017) (Risana \& Kustanti, 2019). Academic stress not only poses a variety of negative impacts, but academic stress can also result in the act of suicide (Dony, 2015). In the research conducted about students who have experienced academic stress results of the incidence of stress, which is $40 \%$ of students experienced stress because of general academic process, $20 \%$ experienced stress for exams, $8 \%$ because of classroom activities, and $8 \%$ in the process Learn (Hurst, Baranik, \& Daniel, 2013)). The academic stress experienced by the students of the final level is in the category of mild stress as much as 14.54 (8 people), moderate stress of $67.28 \%$ (37 people), and who suffered heavy stress as much as $18.18 \%$ (10 people) (Anwar, 2017). Several studies have been conducted, 
found that stress levels will always increase at higher levels of education (Robotham, 2008).

Academic stress in students is caused by several factors, i.e. academic demands that are assessed severely, poor exam results, accumulated tasks, and social environment (Barseli, Ifdil, \& Nikmarijal, 2017), too many tasks, competition between Students, failures, financial factors, poor relations between students and lecturers, and family problems at home (Husnar, Saniah, \& Nashori, 2017). In addition, academic procastination can also cause academic stress in students (Risdiantoro \& Iswinarti, 2016). The factor of the academic stress is diverse which should be a concern for the students themselves and the surrounding people.

Academic stress is not a problem that students experience. Some ways to help students in reducing academic stress include Eye Moving Desensitization and Reprocessing (EMDR) (Henrikus, 2015), Self instruction Counselling techniques (Rachamayanie, Setiawan, \& Fuadi, 2016), restructuring Cognitive (Nurmalasari, Yustiana, \& Ilfiandra, 2016)), Spiritual Emotional treatment Freedom Technique (SEFT) (Adawiyah, 2016), systematic sensitised technique (Odiansyah, 2017), self affirmation Technique (Imamah, 2018), rational-emotive Behavior therapy (Fajar \& Nursalim, 2018), music therapy (Prasetyo, Bakar, \& Bustamam, 2018), expressive writing treatment (Hatmanti \& Rusdianingseh, 2019), Relaxation progressive muscle (Hidayat \& Ilyas, 2019), Cognitive-behavioral therapy (Fatimah, Suherman, \& Rohaeti, 2019), and group counseling with self-management techniques (Vania, Supriatna, \& Fatimah, 2019).

One of the psychotherapy in counseling known as Eye Movement Desensitization and Reprocessing (EMDR) is a well-validated, psychotherapeutic approach that is integrative based on the theory of the Psychopathology caused by traumatic experiences or events that interfere with the journey of Life (Rahmania, 2012). EMDR is also known to be beneficial in improving sleep quality, quality of life and perception of stress (Susanty, 2014). EMDR is a treatment that can apply to clients in helping to deal with certain problems (Astuti, Kep, Amin, \& Purborini, 2018).

EMDR therapy is a therapeutic paradigm that includes neurological sensitivity and psychological sensitivity to relieve stress related to experience or traumatic memory (Susanty \& Sari, 2017). EMDR is also known to be beneficial in improving sleep quality, quality of life and perception of stress (Susanty, 2014). EMDR combines eye movements, recollection of traumatic events, and Verbalization (Rizki, 2017). The client follows the movement of hand or object by the counselor, meaning that the counselor facilitates the client in this EMDR therapy (Susanty \& Sari, 2017). Thus, there is no excess activity that deviates from the general counseling rules. In addition, EMDR in its implementation only takes a short time, and the results got is also effective (Rahmania, 2012). EMDR's own in practice helps clients to lift the mind pile load and stress triggers then replace it with new thinking and more fun and adaptive (Henrikus, 2015).

\section{Method}

In this research researchers used repeated measure design with pretests and multiple posttest design. In this draft, all participants in a single group took part in all experimental treatments, with each group being the controls themselves. The research samples were chosen in purposive, which are 15 semesters of final-level study Program and counseling studies Faculty of Education in Padang State University which has a high level of academic stress and has never been given EMDR Previous. The intervention used is Eye Movement Desensitization and Reprocessing (EMDR). Here researchers tried to explore and elaborate the stages expressed by Shapiro (Brown \& Shapiro, 2006; Shapiro, 2002) (2002): (1) Client history and treatment planning, (2) Preparation, (3) Assessment, (4) Desensitization, (5) installation, (6) Body Scan, (7) Closures, and (8) reevaluation. EMDR is held 2 meetings for each sample.

Data collection is conducted using instruments adapted from Academic Stress Inventory of Students at Universities and Colleges of Technology developed by Lin \& Chen (Lin \& Chen, 2009), comprising stress from teachers, stress from results, Stress from tests, studying in 
group stress, peer stress, time management stress, and self-inflicted stress. The instrument has five subscales, namely highly compliant (SS), corresponding $(\mathrm{S})$, neutral $(\mathrm{N})$, unsuitable (TS) and highly inappropriate (STS) with ranges from 5 completely agree to 1 completely disagree comprising 34 items. The Data obtained is further analyzed using the one-way test of ANOVA for repeated measures (Huck \& McLean, 1975).

\section{Result and Discussion}

Results of analysis using repeated measures there are differences before and after treatment $(\mathrm{F}=$ 274.317; $\mathrm{p}=0.000)$. The average value of student academic stress has decreased on the pretest, Posttest1 and Posttest2. The explanation can be concluded that Eye Movement Desensitization and Reprocessing is effective in reducing academic stress on students. For more details can be seen in table 1

From table 1. Test Result it is known that the results obtained from pretest, posttest 1 and posttest 2 experience changes in academic stress scores. The results of the pretest illustrate the academic stress conditions of students who have not received any treatment.

Table 1. Test result

\begin{tabular}{lccccc}
\hline & Pretest & Posttest1 & Posttest2 & F & P \\
\hline Mean & 144.467 & 112.267 & 85.200 & 274.317 & 0.000 \\
SD & 2.635 & 6.120 & 5.573 & & \\
\hline
\end{tabular}

It is known that the mean and standard deviation based on the results of data collection that has been done at the pretest has a value of 114, 467 with an SD of 2,635. In the posttest 1 results there was a decrease in the mean value to 112,267 with SD of 6,120 and in the posttest 2 result which was the result after 2 treatments, the Mean value showed a decrease back to 85,200 with an SD value of 5,573. Furthermore, a description of the reduction in mean scores from pretest to posttest 2 can be seen in the following diagram.

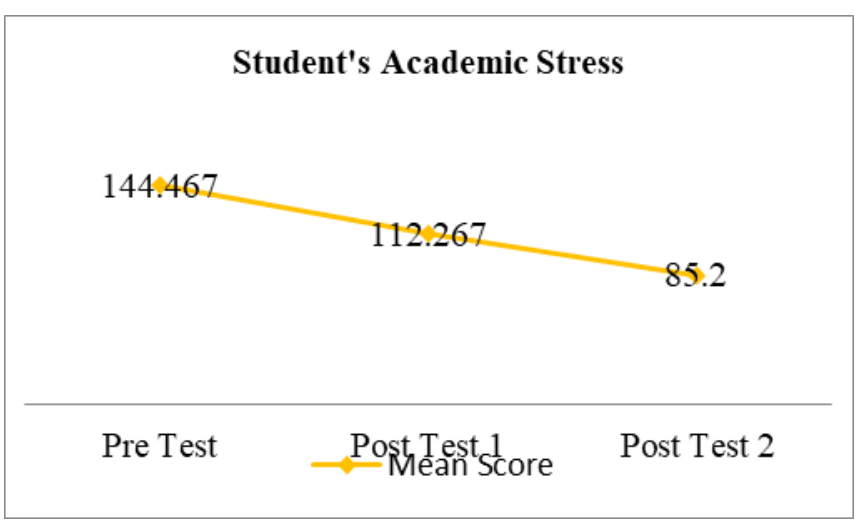

Table 2. Student Academic Stress
This also explains that giving EMDR basically helps reduce the level of academic stress that occurs in students who are known through the Mean value which has decreased from Pretest, posttest 1 and posttest 2 . Obviously this also shows that the more intense the treatment is given to students, the less the level perceived academic stress.

The effectiveness of Eye Movement Desensitization and Reprocessing can be seen in table 2. The results of the pair-wise calculations comparisons academic stress of students show the difference in the average value of pretest-Posttest 2 is greater than that of pretest-posttest1, while the average value difference of posttest1-Posttest 2 is significant. 


\begin{tabular}{lcc}
\hline \multicolumn{1}{c}{ Comparison } & MD & SE \\
\hline Pretest - Posttest1 & $32.200^{*}$ & 7.588 \\
Pretest - Posttest2 & $59.267^{*}$ & 5.741 \\
Posttest1 - Posttest2 & $27.067^{*}$ & 9.149 \\
\hline
\end{tabular}

Based on table 2. It is known that the value of the comparison between the score pretest and posttest 2 has the greatest value among other comparative values that also exist in the table (pretest-posttest 1 and posttest 1-posttest 2). In line with the previous explanation, this condition certainly shows a decrease in academic stress scores experienced by students after undergoing two treatments. The comparison can also be seen in the following diagram.

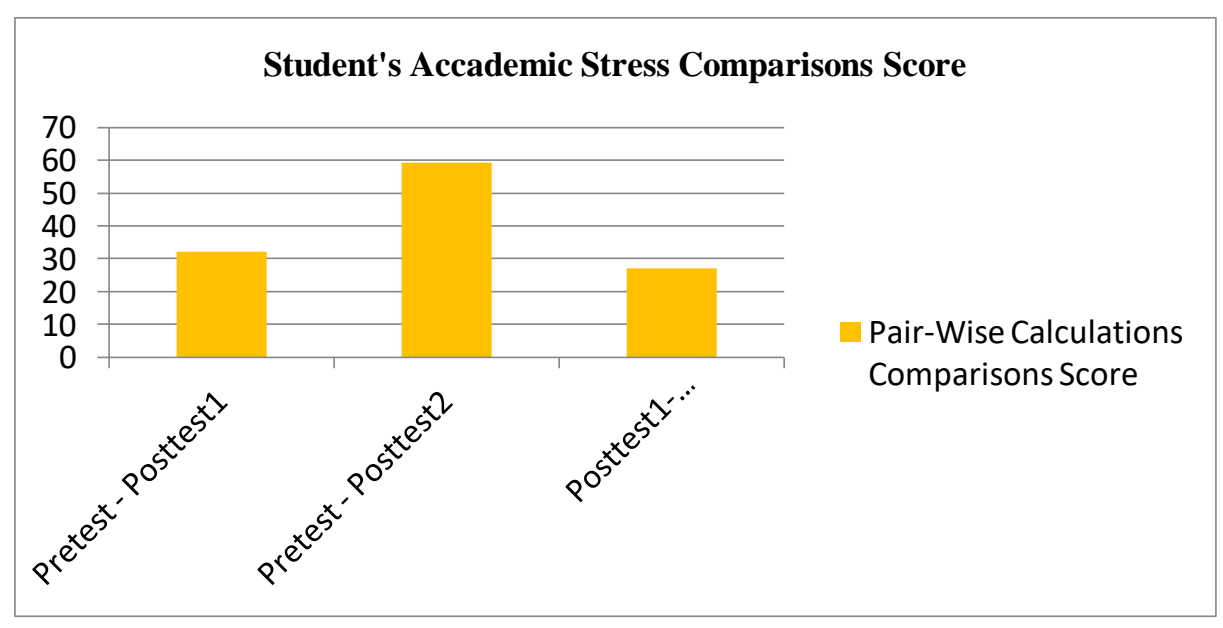

Referring to the research results above, then what is found in this study in line with the opinions of Beer \& Bronner (Beer \& Bronner, 2010) who mentioned that with EMDR various stress reactions, the resulting stress from memories disrupting the life experience can reduced. The results of the study also correspond to the research of Henrikus (Henrikus, 2015) that implementing EMDR can lower the level of academic stress in students. Research conducted earlier by Hyer \& Brandsma (Hyer \& Brandsma, 1997) that EMDR is a therapy roughly equal in efficacy to others available. It is argued that this treatment method is efficacious independent of the value of its parts (e.g., eye movements) and is successful because it applies common and accepted principles of psychotherapy. While Wilson, Tinker, Becker \& Logan (Wilson, Tinker, Becker, \& Logan, 2001) in his article reviewing the effects of EMDR were maintained at the 6 month follow-up, showing enduring gains from a relatively brief treatment regimen for this subclinical sample of officers who were Experiencing some level of stress from their job.

\section{Conclusion}

Eye Movement Desensitization and Reprocessing (EMDR) are implemented as well as the implementation of counseling. This research was conducted to see the effectiveness of EMDR in reducing academic stress to students. The results of the research that has been done show EMDR effectively significantly in the reduction of academic stress on students. It is based on the results of pretests and posttest students before and after the treatment is given. Further results from pair-wise comparisons academic stress of students also show its effectiveness significance. Therefore, this therapy can be used as an alternative therapy to reduce academic stress. EMDR is implemented with a simple but effective enough to support the client to effectively implement daily life. 


\section{References}

[1] Adawiyah, W. (2016). Terapi Spiritual Emotional Freedom Technique (Seft) untuk Menurunkan Tingkat Stres Akademik pada Siswa Menengah atas Di Pondok Pesantren. Jurnal Ilmiah Psikologi Terapan, 4(2), 228245.

[2] Akgun, S., \& Ciarrochi, J. (2003). Learned resourcefulness moderates the relationship between academic stress and academic performance. Educational Psychology, 23(3), 287-294.

[3] Astuti, N. R. T., Kep, M., Amin, N. M. K., \& Purborini, N. N. (2018). Manajemen Penanganan Post Traumatik Stress Disorder (PTSD) Berdasarkan Konsep Dan Penelitian Terkini: Unimma Press.

[4] Barseli, M., Ahmad, R., \& Ifdil, I. (2018). Hubungan stres akademik siswa dengan hasil belajar. Jurnal EDUCATIO: Jurnal Pendidikan Indonesia, 4(1), 40-47.

[5] Barseli, M., Ifdil, I., \& Nikmarijal, N. (2017). Konsep stres akademik siswa. Jurnal Konseling dan Pendidikan, 5(3), 143-148.

[6] Beer, R., \& Bronner, M. B. (2010). EMDR in paediatrics and rehabilitation: An effective tool for reduction of stress reactions? : Taylor \& Francis.

[7] Brown, S., \& Shapiro, F. (2006). EMDR in the treatment of borderline personality disorder. Clinical Case Studies, 5(5), 403-420.

[8] Dony, P. R. (2015). Hubungan antara kecerdasan emosi dan tingkat depresi dengan ide bunuh diri pada peserta didik kelas $\mathrm{X}$ SMK Farmasi Surabaya. Character: Jurnal Penelitian Psikologi., 2(3).

[9] Fajar, S. N., \& Nursalim, M. (2018). Konseling Individu Pendekatan Rational-
Emotive Behavior Therapy untuk Mengurangi Stres Akademik Siswa Kelas XII MIA SMAN 1 Babadan Ponorogo. Jurnal BK UNESA, 9(1).

[10] Fatimah, S., Suherman, M. M., \& Rohaeti, E. E. (2019). Penerapan Cognitive-Behavioral Therapy dalam Meningkatkan Locus of Control Peserta Didik yang Mengalami Stres Akademik. Jurnal Penelitian Bimbingan dan Konseling, 4(2).

[11] Hatmanti, N. M., \& Rusdianingseh, R. (2019). Expressive Writing Treatment terhadap Stres Mahasiswa Di Prodi S1 Keperawatan: Expressive Writing Intervention for Academic Stress of Nursing Students. Jurnal Ilmiah Keperawatan (Scientific Journal of Nursing), 5(2), 126-130.

[12] Henrikus, H. (2015). Penerapan Eye Moving Desensitization And Reprocessing (EMDR) Untuk Menurunkan Tingkat Stres Akademik Pada Siswa Kelas XI Pekerjan Sosial 2 Di SMK Negeri 7 Makassar

[13] Hidayat, I., \& Ilyas, A. (2019). Efektivitas Relaksasi Otot Progresif untuk Mereduksi Stres Akademik Siswa sebagai Teknik dalam Layanan BK. e-Journal Pembelajaran Inovasi, Jurnal Ilmiah Pendidikan Dasar, 7(1).

[14] Huck, S. W., \& McLean, R. A. (1975). Using a repeated measures ANOVA to analyze the data from a pretest-posttest design: a potentially confusing task. Psychological Bulletin, 82(4), 511.

[15] Hurst, C. S., Baranik, L. E., \& Daniel, F. (2013). College student stressors: A review of the qualitative research. Stress and Health, 29(4), 275-285.

[16] Husnar, A. Z., Saniah, S., \& Nashori, F. (2017). Harapan, tawakal, dan stres akademik. Psikohumaniora: Jurnal Penelitian Psikologi, 2(1), 94-105. 
[17] Hyer, L., \& Brandsma, J. M. (1997). EMDR minus eye movements equals good psychotherapy. Journal of Traumatic Stress, 10(3), 515-522.

[18] Lazarus, R. S., \& Folkman, S. (1984). Coping and adaptation. The handbook of behavioral medicine, 282325.

[19] Lin, Y. M., \& Chen, F. S. (2009). Academic stress inventory of students at universities and colleges of technology. World Transactions on Engineering and Technology Education, 7(2), 157-162.

[20] Nomor, P. (2015). tentang Standar Nasional Pendidikan Tinggi. Jakarta: Kemenristekdikti.

[21] Nurmalasari, Y., Yustiana, Y. R., \& Ilfiandra, I. (2016). Efektivitas restrukturisasi kognitif dalam menangani stres akademik siswa. Jurnal Penelitian Bimbingan dan Konseling, 1(1).

[22] Odiansyah, F. (2017). Bimbingan konseling Islam dengan pendekatan behavioristik melalui teknik disensitasi sistematis untuk menangani stres akademik siswa: studi kasus di SMPN 1 Kedamean Kecamatan Kedamean Kabupaten Gresik. UIN Sunan Ampel Surabaya.

[23] Prasetyo, D., Bakar, A., \& Bustamam, N. (2018). Terapi Musik untuk Mengurangi Tingkat Stres Akademik pada Siswa SMA Negeri 5 Banda Aceh. JIMBK: Jurnal Ilmiah Mahasiswa Bimbingan \& Konseling, 3(3).

[24] Rachamayanie, R., Setiawan, M. A., \& Fuadi, A. S. (2016). Keefektifan Teknik 'SelfInstruction'dalam Mengurangi Stres Akademik pada Mahasiswa Bimbingan dan Konseling Angkatan 2013 FKIP ULM Banjarmasin.

[25] Rahmania, A. R. (2012). Perbedaan Pengaruh Eye Movement Desensitization And Reprocessing (Emdr) Dengan Teknik Stabilisasi Untuk Menurunkan Posttraumatic
Stress Disorder (Ptsd) Pada Penyandang Tuna Daksa Pasca Mengalami Kecelakaan Lalu Lintas. Universitas Muhammadiyah Surakarta.

[26] Risana, I. W., \& Kustanti, E. R. (2019). Hubungan antara Hardiness dengan Stres Akademik pada Mahasiswa Departemen Teknik Sipil Universitas Diponegoro. UNDIP.

[27] Risdiantoro, R., \& Iswinarti, H. N. (2016). Hubungan prokrastinasi akademik, stres akademik, dan kepuasan hidup mahasiswa. Pshychology \& Humanity, 19(20), 360-373.

[28] Rizki, D. S. (2017). Eye Movement Desensitization And Reprocessing (EMDR) untuk Menurunkan PTSD pada Korban Inses. Humanitas: Jurnal Psikologi Indonesia, 14(1), 57-65.

[29] Robotham, D. (2008). Stress among higher education students: Towards a research agenda. Higher education, 56(6), 735-746.

[30] Rusdi, R. (2015). Hubungan antara efikasi diri dan manajemen waktu terhadap stres mahasiswa farmasi semester iv Universitas Mulawarman. Jurnal Psikologi, 4(1), 53-64.

[31] Shapiro, F. E. (2002). EMDR as an integrative psychotherapy approach: Experts of diverse orientations explore the paradigm prism: American Psychological Association.

[32] Simbolon, I. (2015). Reaksi stres akademis mahasiswa keperawatan dengan sistem belajar blok di fakultas keperawatan $\mathrm{x}$ bandung. Jurnal Skolastik Keperawatan, 1(01), 130175.

[33] Susanty, E. (2014). Treatment EMDR (Eye Movement Desensitization and Reprocessing) bagi Korban Bencana Gempa: Studi Kasus. Jurnal Reliabel, 1(1).

[34] Susanty, E., \& Sari, D. I. (2017). Penanganan Gejala Traumatik dengan Terapi Emdr (Eye Movement Desensitization And Reprocessing) pada Narapidana Wanita di Lapas Kelas Iia Bandung, Jawa Barat. INQUIRY: Jurnal Ilmiah Psikologi, 8(1), 1-15. 
[35] Vania, N. R., Supriatna, E., \& Fatimah, S. (2019). Penerapan Konseling Kelompok dengan Teknik Self Management dalam Rangka Pengelolaan Stres Akademik Peserta Didik Kelas VIII SMP. Fokus (Kajian Bimbingan \& Konseling dalam Pendidikan), 2(6), 102-116.

[36] Wilson, S. A., Tinker, R. H., Becker, L. A., \& Logan, C. R. (2001). Stress management with law enforcement personnel: A controlled outcome study of EMDR versus a traditional stress management program. International Journal of Stress Management, 8(3), 179-200.

[1] Yuliasih, Y., \& Akmal, S. Z. (2017). Peran Wisdom dan Knowledge terhadap Resiliensi pada Mahasiswa yang Mengalami Stres Akademik. Intuisi: Jurnal Psikologi Ilmiah, 9(2), 1-15. 